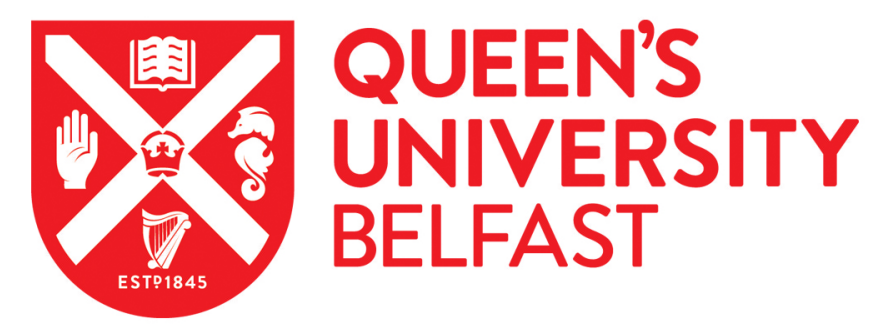

\title{
The current evidence on statin use and prostate cancer prevention: are we there yet?
}

Alfaqih, M. A., Allott, E. H., Hamilton, R. J., Freeman, M. R., \& Freedland, S. J. (2017). The current evidence on statin use and prostate cancer prevention: are we there yet? Nature reviews. Urology, 14(2), 107-119. https://doi.org/10.1038/nrurol.2016.199

\section{Published in:}

Nature reviews. Urology

Document Version:

Peer reviewed version

Queen's University Belfast - Research Portal:

Link to publication record in Queen's University Belfast Research Portal

Publisher rights

(C) 2019 Springer Nature Publishing AG.

This work is made available online in accordance with the publisher's policies. Please refer to any applicable terms of use of the publisher.

\section{General rights}

Copyright for the publications made accessible via the Queen's University Belfast Research Portal is retained by the author(s) and / or other copyright owners and it is a condition of accessing these publications that users recognise and abide by the legal requirements associated with these rights.

Take down policy

The Research Portal is Queen's institutional repository that provides access to Queen's research output. Every effort has been made to ensure that content in the Research Portal does not infringe any person's rights, or applicable UK laws. If you discover content in the Research Portal that you believe breaches copyright or violates any law, please contact openaccess@qub.ac.uk. 


\section{Statins and prostate cancer prevention: are we there yet?}

Mahmoud A. Alfaqih ${ }^{1}$, Emma H. Allott ${ }^{2}$, Robert J. Hamilton ${ }^{3}$, Michael R. Freeman ${ }^{4}$ and Stephen

J. Freedland ${ }^{4}$

${ }^{1}$ Department of Surgery, Duke University, Durham, North Carolina

${ }^{2}$ Department of Nutrition and Lineberger Comprehensive Cancer Center, University of North Carolina, Chapel Hill, North Carolina

${ }^{3}$ Department of Urology, University of Toronto, Toronto, Canada

${ }^{4}$ Department of Surgery and Samuel Oschin Comprehensive Cancer Institute, Cedars-Sinai Medical Center, Los Angeles, California

Corresponding author: Dr. Stephen J. Freedland; Mailing address: Cedars-Sinai Medical Center, 8635 West 3rd Street, Suite 1070W, Los Angeles, CA 90048, USA; Tel: 310-423-3497; Fax: 310-423-4711; Email: stephen.freedland@ cshs.org

Key Words: Hypercholesterolemia, Statin, Prostate cancer, Chemoprevention Text Word Count: 5,008

Mailing addresses: 
Mahmoud A. Alfaqih: Division of Urology, Department of Surgery, Duke University School of Medicine, Box 2626, Durham NC 27710, USA.

Emma H. Allott: Department of Nutrition, CB 7461, University of North Carolina at Chapel Hill, 135 Dauer Drive, Chapel Hill, NC 27599, USA

Robert J. Hamilton: Division of Urology, Department of Surgical Oncology, University of Toronto, 610 University Avenue, Toronto, Ontario M5G 2M9, Canada

Michael R. Freeman: Division of Cancer Biology and Therapeutics, Departments of Surgery and Biomedical Sciences, Samuel Oschin Comprehensive Cancer Institute, Cedars-Sinai Medical Center, 8700 Beverly Boulevard, Los Angeles, CA 90048, USA

Stephen J. Freedland: Cedars-Sinai Medical Center, 8635 West 3rd Street, Suite 1070W, Los Angeles, CA 90048, USA

\section{Biographies}

Dr. Mahmoud A. Alfaqih was previously a Postdoctoral Associate in Pharmacology and Cancer Biology at Duke University and now lives in Jordan with his wife and kids.

Dr. Emma H. Allott is a Research Assistant Professor of Nutrition at the University of North Carolina, Chapel Hill. She received her Ph.D. in molecular cancer biology from Trinity College Dublin, Ireland and trained in population-based methods and study design as a Cancer Prevention, Detection and Control Fellow at Duke University, and as a postdoctoral associate in the Department of Epidemiology at the University of North Carolina, Chapel Hill. Her research integrates epidemiologic methods and design, molecular tumor profiling and experimental model 
systems to understand the role of dietary and lifestyle factors in prostate cancer aggressiveness and progression.

Dr. Robert J. Hamilton is a uro-oncologic surgeon, specializing in cancers (and other conditions) of the genitourinary organs (bladder, kidney, prostate, testes and related urological organs). He has expertise in minimally invasive surgeries. He is also a medical researcher and assistant professor of surgery at University of Toronto Medical School.

Dr. Michael R. Freeman is a Professor in the Departments of Surgery, Medicine and Biomedical Sciences at Cedars-Sinai Medical Center, and a Professor in the Department of Medicine at the University of California, Los Angeles (UCLA). Dr. Freeman and his group have conducted preclinical studies on the role of cholesterol in prostate cancer, on hypertrophic signaling in bladder smooth muscle, molecular mechanisms of interstitial cystitis/pelvic pain syndrome, and a number of aspects of prostate and bladder cancer progression.

Dr. Stephen J. Freedland earned his MD from the University of California, Davis, completed a urology residency at UCLA, and a urological oncology fellowship at Johns Hopkins. Dr. Freedland is director of the Center for Integrated Research in Cancer and Lifestyle, co-director of the Cancer Genetics and Prevention Program, associate director for Faculty Development at the Samuel Oschin Comprehensive Cancer Institute, and faculty physician in the Division of Urology, Cedars-Sinai Department of Surgery. Dr. Freedland's research interests include the role of diet, lifestyle and obesity in prostate cancer development and progression, as well as prostate cancer race disparities and risk stratification. 


\begin{abstract}
Evidence is emerging for an inverse association between statin use and cancer risk. Of all the cancers studied, data for prostate cancer are the most promising, particularly for advanced disease. Epidemiological evidence for such an association is supported by a number of preclinical studies that show statins directly inhibit prostate cancer development and progression in cell-based and animal-based models. The antineoplastic effect of statins may be explained by a number of cholesterol-mediated and non-cholesterol-mediated mechanisms. Understanding these mechanisms is instrumental for future drug discovery efforts for the development of next generation prostate cancer therapeutics as well as for designing clinical trials for statins. In this review, we review possible antineoplastic mechanisms by which statins may exert their anticancer effects. We also analyze the most recent human data regarding the association between statin use and prostate cancer risk. Finally, we discuss areas that, in our opinion, should receive top priority for future funding and research efforts. While currently there are insufficient data to advocate statin use for the primary prevention of prostate cancer, the motivation to move forward with further research is clear.
\end{abstract}




\section{Key points}

- Statins are a commonly-prescribed class of medications that effectively lower serum cholesterol levels by inhibiting 3-hydroxy-3-methylglutaryl coenzyme A (HMG-CoA) reductase, the rate-limiting enzyme for cholesterol synthesis in the liver.

- Animal-based and cell-based preclinical models demonstrate that statins may inhibit prostate cancer growth through cholesterol-mediated (e.g. lipid raft-mediated signaling, de novo steroidogenesis) and non-cholesterol-mediated mechanisms (e.g. Ras signaling) that affect many pathways essential for cancer formation and progression.

- More than 30 observational studies of statin use and prostate cancer risk have been completed to date, with the preponderance of evidence supporting a role for statins in reducing the risk of advanced prostate cancer.

- Elevated rates of PSA screening and health-seeking behaviors in statin users may bias the findings of some epidemiologic studies, but are unlikely to fully explain the association between statin use and prostate cancer. Inverse associations between statin use and risk of advanced prostate cancer have been reported both by European and North American studies (populations with low and high PSA screening rates, respectively).

- Statin use has also been associated with improved prostate cancer-specific survival, suggesting a potential role for statins in secondary and tertiary prostate cancer prevention. These epidemiologic findings are particularly pronounced in men undergoing radiation therapy, and laboratory studies support a role for statins in radio-sensitizing prostate tumor cells.

- Prior to conducting primary prevention trials, there is a need for further basic research in order to understand the mechanisms contributing to inverse associations reported by 
observational studies. However, statin secondary and tertiary prevention trials with a goal to improve therapeutic outcomes for men already diagnosed with prostate cancer may be realized in the not too distant future. 


\section{Introduction}

Statins refer to a class of medications that effectively lower serum cholesterol levels by inhibiting 3-hydroxy-3-methylglutaryl coenzyme A (HMG-CoA) reductase, the rate-limiting enzyme for cholesterol synthesis in the liver. In view of the epidemic nature of hyperlipidemia in the United States ${ }^{1}$, statins are becoming one of the most commonly prescribed medications. In 2012, more than one in four US adults over 40 years of age reported using statins, with simvastatin the most commonly used ( $42 \%$ of all statin users), followed by atorvastatin (20\% of all statin users) ${ }^{2}$. There is unequivocal evidence that statins reduce the number of adverse cardiovascular events associated with hyperlipidemia ${ }^{3}$; more recently, however, evidence is growing for a potential role for statins in chemoprevention ${ }^{4-11}$. Statins have been linked with reduced risk of several cancer types, with the most promising evidence supporting a role for statins in preventing prostate cancer, especially more advanced forms ${ }^{6-11}$. However, as not all data agree on the potential benefits of statins, especially regarding the potential role of statins in reducing risk of total prostate cancer, it is still too early to advocate that all men start statins as a chemopreventative measure for prostate cancer $^{3,12,13}$.

In this review, we will thoroughly present the most current evidence both for and against a potential role for statins in the chemoprevention of prostate cancer. We will review pre-clinical studies that examined the molecular mechanisms of how statins may inhibit prostate cancer growth using cell-based and animal-based models. We will then critically examine the most recent human data that studied associations between statins and prostate cancer, and special emphasis will be given to accumulating evidence that supports a role for statins in preventing advanced prostate cancer and prostate cancer progression. Finally, we will discuss the current 
gaps in our understanding of how statins may modify prostate cancer risk that must be filled in order to better guide future research and funding strategies.

\section{Statin medications: the basics}

It is well established that statins reduce the number of adverse cardiovascular events associated with hyperlipidemia. This is achieved by lowering total serum cholesterol and low density lipoprotein (LDL) cholesterol levels secondary to inhibition of hepatic HMG-CoA reductase, an enzyme that catalyzes the rate-limiting step in hepatic cholesterol biosynthesis ${ }^{3}$. Statins can be classified as either hydrophilic or lipophilic with respect to their solubility (Table 1) ${ }^{14}$. Hydrophilic statins are more hepatoselective given their active transport into the liver and their exclusion by other tissue types. As such, lipophilic statins have been hypothesized to have a greater influence on the prostate, although this has not been conclusively demonstrated by observational studies of statins and prostate cancer risk (Table 2) ${ }^{6,15-17}$. Statins are generally well tolerated with the most common side effects being hepatic dysfunction and muscle myopathies. A meta-analysis of 35 clinical trials of statin users vs. non-users concluded that statin therapy is only associated with a small excess risk of hepatic dysfunction but not of myalgias, rhabdomyolysis or creatine kinase elevations (a marker of myopathy) ${ }^{18}$. Another meta-analysis of 13 clinical trials showed that statin use was associated with a slightly elevated risk of new-onset diabetes, although this risk was offset by the cardiovascular benefits of statins 19.

In view of the efficacy and safety of statins, it is not surprising to know that once the first statin, lovastatin, was approved by the United States Food and Drug Administration in 1987, six others joined lovastatin and collectively the market for statins has been growing ever since (Figure 1) ${ }^{20,21}$. Interestingly, the cardiovascular benefits of statin use have been observed in 
users that don't have elevated cholesterol ${ }^{22}$ suggesting that statins may have other actions in addition to cholesterol lowering. These findings regarding the "pleiotropic" effects of statins lend support to the rationale to examine whether statins may modify cancer risk.

\section{Understanding the basic science of statins and prostate cancer prevention}

Considering the mounting evidence from human studies supporting a role for statins in modifying prostate cancer risk, it becomes essential to decipher potential mechanisms that could explain any benefits of statins at the molecular level using established animal-based and cellbased preclinical models. As summarized in Figure 2, there is currently wealth of data from these models demonstrating that statins may inhibit prostate cancer growth through cholesterolmediated and non-cholesterol-mediated mechanisms that affect many pathways essential for cancer formation and progression. Specifically, using these models, statins have been shown to inhibit prostate cancer inflammation ${ }^{23}$, angiogenesis ${ }^{24}$, cell proliferation ${ }^{25}$, migration/adhesion

${ }^{26}$, and invasion ${ }^{27}$, and to promote apoptosis ${ }^{28}$. Moreover, inhibition of HMG-CoA reductase by statins lowers the concentration of mevalonate and consequently the downstream isoprenylated intermediates believed to play an essential role in signaling pathways that support cancer formation and progression ${ }^{29}$.

\section{Cholesterol-mediated pathways}

As early as 1981, Schaffner noted a positive correlation between cholesterol accumulation in prostatic tissues and the presence of prostate cancer ${ }^{30}$. Several mechanisms have since been shown to contribute to dysregulation of cholesterol homeostasis in prostate cancer. One study found that hypermethylation of the cholesterol efflux transporter ABCA1 resulted in reduced ABCA1 expression, lower cholesterol efflux rates and elevated levels of intracellular cholesterol in prostate cancer cell lines, and this epigenetic alteration was associated 
with high-grade prostate cancer in humans ${ }^{31}$. Activation of the mTOR pathway plays an important role in regulating sterol responsive element binding proteins (SREBPs), transcription factors that control lipid and cholesterol homeostasis ${ }^{32}$. Indeed, another study reported that intracellular accumulation of cholesteryl ester in lipid droplets was driven by loss of the tumor suppressor, PTEN, and subsequent activation of the PI3K/Akt/mTOR signaling pathway, and that intracellular accumulation of cholesterol ester was associated with high-grade prostate cancer in humans ${ }^{33}$.

One of the major cholesterol-mediated mechanisms through which statins inhibit tumour growth involves specialized cholesterol-rich regions of the membrane known as lipid rafts ${ }^{34}$. These domains facilitate membrane-initiated signaling events in the cell through compartmentalization of signaling pathways, thereby enhancing tumour growth. Cell signaling pathways implicated in prostate cancer development and progression which may be mediated by cholesterol composition of lipid rafts include androgen receptor ${ }^{35}$, epidermal growth factor receptor (EGFR) ${ }^{36}$ and luteinizing hormone receptor ${ }^{37}$ pathways. It is believed that statins, through their effect on intracellular cholesterol homeostasis, disrupt organization of these specialized domains and thus interfere with the above or other downstream intracellular signaling pathways ${ }^{38}$.

A direct example of the effect of reducing cholesterol content of the rafts on membraneinitiated signaling is EGFR, a cell membrane-bound receptor recently found to associate with lipid rafts in prostate cancer cells ${ }^{36}$. EGFR activation leads to Akt activation, a potent promoter of the growth of several solid tumour types, including prostate cancer ${ }^{39}$. It has been shown that pharmacological treatment of prostate cancer cells with cholesterol binders disrupted lipid raft organization and interfered with EGFR signaling ${ }^{36}$. Moreover, a recent study found that 
activation of cholesterol efflux in LNCaP cells and xenografts through pharmacological treatment with a Liver X Receptor (LXR) agonist induced apoptosis through disruption of lipid rafts and consequent downregulation of Akt signaling ${ }^{40}$. Other signaling pathways implicated in prostate cancer and development of castration resistance such as interleukin-6 activation or signal transducer and activator of transcription-3 (STAT-3) have similarly been found to be associated with lipid raft organization and thus are under the potential influence of lipid raft cholesterol concentrations ${ }^{41}$. The importance of cholesterol has also been seen in a mouse model. Mice were fed a high-fat, high-cholesterol diet and injected with LNCaP subcutaneous xenografts and were compared to mice consuming a low-fat, low-cholesterol diet. Elevated cholesterol in the serum of high-fat fed mice promoted tumour growth and reduced apoptosis, in part by increasing activity of Akt. Interestingly, inhibition of cholesterol synthesis with a statin disrupted lipid rafts in the tumours and induced apoptosis through attenuation of Akt signaling ${ }^{42}$.

Alternatively, with cholesterol being a precursor for androgens, lowering cholesterol levels using statins may reduce prostate cancer growth by reducing serum or intra-tumoural levels of androgens. The effect of statins on serum androgen levels of is unclear. While some studies have suggested statins reduce serum testosterone levels ${ }^{43-45}$, these reductions are small or associated with higher statin doses than used in common clinical practice. Other observational studies ${ }^{46,47}$, and two clinical trials ${ }^{48,49}$ found no association between statin use and serum androgen levels. Most recently, a nested study of 1,812 men in the Boston Area Community Health Survey cohort, of which 237 (12.4\%) were statin users, found no association between statin use and serum androgen levels ${ }^{50}$.

Emerging evidence suggests that even when castrate levels of androgens are achieved in the serum of prostate cancer patients, intra-prostatic levels of androgen remain high possibly due 
to de novo androgen synthesis ${ }^{51-53}$. Thus, it remains conceivable that statins, by lowering intraprostatic cholesterol levels, could lower intra-prostatic androgen levels. Indeed, a recent study found that hypercholesterolemia induced in non-castrated mice by a high fat, high cholesterol diet increased the intra-tumoural levels of androgens in $\mathrm{LNCaP}$ xenografts without having an effect on serum androgens, suggesting that hypercholesterolemia induces intra-tumoural de novo steroidogenesis ${ }^{54}$.

Non-cholesterol-mediated pathways

Statins inhibit the conversion of HMG-CoA to mevalonate thereby reducing mevalonate cellular concentrations. Mevalonate is a precursor for a class of compounds called isoprenoids, such as farnesyl pyrophosphate (FPP) and geranylgeranyl pyrophosphate (GPP). FPP and GPP facilitate the recruitment of signaling proteins such as the Ras/Rho family of G-proteins by bridging their attachment to the plasma membranes where their signaling activities can promote prostate cancer cell survival and proliferation ${ }^{55,56}$. Thus, statins, by reducing mevalonate and downstream isoprenoids may inhibit cancer cell proliferation.

Furthermore, statins appear to directly induce apoptosis in cancer cells independent of their effect on cholesterol. This has been reviewed elsewhere ${ }^{29}$, but with respect to prostate cancer statins can, for example, inhibit cyclin-dependent kinase-2 and stimulate cell-cycle arrest ${ }^{57}$, or even activate specific proteases that themselves can later activate apoptosis ${ }^{58}$. Statins also have direct anti-inflammatory and anti-angiogenic properties which conceivably may also inhibit cancer growth and progression ${ }^{29}$. A recent study in a cohort of men undergoing radical prostatectomy at a VA medical center found that statin users have significantly lower levels of prostate inflammation within their prostate tumours than non-users ${ }^{59}$.

\section{Evidence from epidemiologic studies: statins and prostate cancer prevention}


In the last few years there has been increasing interest in the use of statins for prostate cancer prevention ${ }^{60}$. It has even been suggested that statins may be partially responsible for the steep decline in the prostate cancer mortality rate witnessed over the last 15 years ${ }^{61}$ as it paralleled the introduction and distribution of statins (Figure 1). Upon closer inspection of epidemiologic studies and secondary analyses of randomized controlled trials, it appears that the preponderance of evidence supports a role for statins in reducing prostate cancer risk with the strongest evidence to date supporting that statins may selectively lower the risk of advanced prostate cancer. As outlined in this section, in addition to data supporting an inverse association between statin use and risk of advanced prostate cancer, there is also evidence that statins may impact prostate cancer progression at multiple stages of the disease course including biochemical recurrence after primary therapy, development of castrate resistance following androgen deprivation therapy, and prostate cancer-specific mortality (Figure 3).

\section{Total prostate cancer}

More than 30 observational studies (summarized in Table 2) have examined the link between statin use and total prostate cancer risk with encouraging, though conflicting results. A number of case-control studies reported null associations ${ }^{7,15,62-64}$, but three reported an elevated risk of total prostate cancer in statin users ${ }^{10,65,66}$. However, one of these studies suggested that the positive association between statin use and total prostate cancer risk is potentially attributable to bias arising from increased surveillance in men initiating statin treatment ${ }^{10}$. Indeed, the Finnish study found that the elevated prostate cancer risk in new statin users disappeared with increasing duration of statin use, supporting this possible explanation ${ }^{66}$. The largest populationbased case-control study to date, a Danish study that included more than 40,000 total prostate 
cancer cases and over 200,000 controls, reported a significant $6 \%$ reduced risk of total prostate cancer in statin users ${ }^{17}$.

A cohort study of $>55,000$ men in the Veterans Administration (VA) Health System found statin users were $31 \%$ less likely to be diagnosed with total prostate cancer ${ }^{67}$. Two cohort studies examining men undergoing PSA screening found a $25 \%{ }^{68}$ and $64 \%{ }^{69}$ reduced prostate cancer risk in statin users, while a cohort study examining men undergoing prostate biopsy reported a $8 \%$ reduced risk of total prostate cancer in statin users ${ }^{70}$. A retrospective cohort in Israel found a $74 \%$ reduced risk of total prostate cancer in long-term statin users, defined as at least 5 years of statin use, relative to non-users ${ }^{71}$. Other studies found weaker, but still inverse associations between statin use and total prostate cancer risk ${ }^{72,73}$, including a population-based study in Washington State that found statin users had a $12 \%$ lower prostate cancer risk (HR 0.88 , 95\% CI, 0.76-1.02), though this did not reach significance ${ }^{16}$. Despite these promising data, other studies found no link between statin use and total prostate cancer risk, including a secondary analysis of a randomized trial of men with a negative prostate biopsy who underwent repeat biopsies at two and four years ${ }^{74}$, in addition to several observational studies ${ }^{5,11,75-78}$. Despite conflicting findings from individual case-control and cohort studies, the most recent metaanalysis of these studies reported a $7 \%$ significantly reduced risk of total prostate cancer in statin users $^{79}$.

Multiple meta-analyses of randomized controlled trials of statin use in the primary and secondary prevention of adverse cardiovascular outcomes reported null associations between statin use and total prostate cancer risk ${ }^{80-82}$. It is widely acknowledged that trial participants may not be representative of the general population. For example, all statin trials incorporated dietary interventions in both statin and placebo groups and all trial participants had a history of 
cardiovascular disease ${ }^{3}$. Furthermore, while the most commonly-used statin in the United States is simvastatin (Table 1$)^{2}$, the majority of clinical trials randomized participants to pravastatin, a weaker inhibitor of HMG-CoA reductase with reduced cholesterol-lowering efficacy ${ }^{83}$. Finally, randomized controlled trials have relatively short follow-up periods, with a median of 4.8 years of follow up across the 27 statin trials to date ${ }^{80}$. Together, these factors could explain differences in associations between statin use and total prostate cancer risk reported by observational studies and randomized trials.

\section{Advanced prostate cancer}

While the data examining associations between statins and total prostate cancer are unclear, there are increasing data indicating that statins may selectively lower the risk of advanced prostate cancer, with advanced prostate cancer defined using Gleason grade, clinical stage or a combination of both variables (Table 2). Indeed, five large prospective studies all found that statin users had reduced risk of advanced prostate cancer without any reduction or with a greatly attenuated reduction in total prostate cancer risk ${ }^{8,9,11,67,84}$.

The Health Professionals Follow-up Study followed 34,989 men who were cancer free in 1990 until $2002^{8}$. In this study, statin use was associated with a $49 \%$ reduced risk of advanced prostate cancer and a $61 \%$ reduced risk of metastatic or fatal prostate cancer. Interestingly, statin use was not associated with risk of total prostate cancer. Moreover, among men with $\geq 5$ years of statin use, the risk of advanced prostate cancer was reduced by $74 \%$.

The Cancer Prevention Study II Nutrition Cohort $(n=55,454)^{9}$, the California Men's Health Cohort Study $(\mathrm{n}=69,047)^{11}$, and a case-control study set in the Finnish population $(n=24,723)^{10}$, observed $40 \%, 20 \%$ and $25 \%$ reductions respectively in the risk of advanced prostate cancer among longer-term ( $\geq 5$ years ${ }^{9,11}$ or $\geq 915$ defined daily doses $\left.{ }^{10}\right)$ statin users. 
Although the risk reduction observed in the California Men's Health Cohort did not reach statistical significance, the study findings are still encouraging considering the low number of men diagnosed with advanced prostate cancer $(n=131)$. The introduction of bias was minimized in all four studies by controlling for potential confounding variables including use of other medications, diabetes, diabetes treatments and other cardiovascular risk factors that are associated with prostate cancer such as age, race and body mass index.

More recently, in 2012, a meta-analysis of 27 observational studies found that statin use was associated with only a modest reduction in total prostate cancer risk (7\%) but a more pronounced reduction in advanced disease risk $(20 \%)^{79}$. Since then, four additional studies reported an inverse association between statin use and lethal prostate cancer; a case only analysis of 1,001 prostate cancer patients of whom 289 were statin users reported a hazard ratio (HR) of 0.19 (95\% CI: $0.06,0.56)$ of prostate cancer-specific mortality for statin users versus non-users 85. A registry-based study in a Danish population where statin use began before cancer diagnosis found that statin users had significantly lower prostate cancer-specific mortality, and this finding was also observed for 12 other cancer types ${ }^{86}$. A study originally designed to assess the association between beta blockers and prostate cancer-specific mortality found that statin use was inversely associated with lethal prostate cancer among $3,561 \mathrm{men}{ }^{87}$. Finally, a study conducted in a large, population-based electronic database in the United Kingdom found that use of statins was even more strongly associated with a lower risk of lethal disease if started before diagnosis ${ }^{88}$.

PSA testing is the most widely-used method for prostate cancer screening. The implication of this is if statin use affects PSA levels, bias would potentially be introduced in all of the above observational studies. Indeed, a pilot study of 15 statin users demonstrated that 
statin use caused a $42 \%$ decline in PSA levels over a period of five years ${ }^{89}$. To investigate how statin use affected PSA levels at the time of prostate cancer screening, we conducted a cross sectional study of 323,426 men aged $\geq 65$ years who had a screening PSA test in 2003 at a VA facility. We found that statin use was associated with a lower probability that an older man will have an abnormal screening PSA result, regardless of the PSA threshold ${ }^{90}$. Another study examined the effect of statin, thiazide diuretics and nonsteroidal anti-inflammatory drugs (NSAIDs) on PSA levels in a cohort of 1,864 men that had no history of prostate cancer, prostatitis, or recent prostate manipulations in the National Health and Nutrition Examination Survey (NHANES), found that statin use was inversely related to PSA levels $(p=0.01)^{91}$. Given the observation that statin use is associated with lower PSA levels at screening, one could imagine that lower PSA levels in statin users would trigger fewer biopsies and thus use of statins would be associated with a decreased incidence of total prostate cancer risk. However, as prostate cancer diagnosis would be delayed in this case, there would be an increased incidence of advanced prostate cancer among statin users. Based on the above discussion, it is unlikely that the effect of statins on PSA levels introduced any significant bias in the findings of the above studies because the exact opposite findings were observed in the vast majority (i.e. reduced risk of advanced disease).

One could also argue that statin users may be more health conscious with more frequent visits to the health care system than non-users. This may make statin users more likely to be diagnosed with prostate cancer at an earlier stage of the disease than non-users. Early detection of prostate cancer and subsequent early treatment is associated with less frequent progression to advanced stages of the disease and may explain lower risk of advanced prostate cancer observed in statin users. However, a number of studies reported that adjusting for the intensity of PSA 
screening did not impact the association between statin use and risk of advanced disease ${ }^{73,92,93}$. The most recent meta analysis reported that the findings of studies adjusting for PSA screening did not greatly differ from the findings of studies that did not adjust for PSA screening ${ }^{79}$. Meanwhile, considering that the prevalence of PSA testing in Europe is exceedingly lower than in the United States, this makes the case-control studies set in Denmark and Finland relatively free from this potential bias ${ }^{94}$. Yet, these studies also observed a significant reduction in the risk of advanced prostate cancer as did studies in the United States.

\section{Can statins in combination with prostate cancer therapies improve prostate cancer} outcomes?

In addition to statins' role as a potential agent for prostate cancer chemoprevention, investigators are beginning to study whether statins may improve the outcome of wellestablished prostate cancer therapies. In a study of 938 men treated with brachytherapy, Moyad et al. compared outcomes of men taking statins $(n=191)$ to non-statin users ${ }^{81}$. Statin users had smaller prostate volumes, lower PSA values and lower tumour volume in the biopsy specimens. There was a suggestion that statin use was associated with improved prostate cancer-specific and overall survival, although this association did not reach statistical significance. In a different study of 871 men with stage T1 to T3 prostate cancer treated with radiotherapy, 168 were taking a statin at the time of diagnosis ${ }^{82}$. In this study, use of statins was a significant predictor of improved PSA-free survival compared to non-users $(p=0.03)^{82}$. Oh et al. retrospectively examined the association between use of statins and risk of biochemical recurrence in prostate cancer patients treated with permanent Iodine-125 brachytherapy at Durham VA Medical Center. In this study, statin use was associated with a significant delay in biochemical recurrence, relative to non-users ${ }^{83}$. Furthermore, a meta-analysis of 13 studies that examined the effect of 
statin use on biochemical recurrence following local treatment with radical prostatectomy or radiotherapy found that statins were associated with a statistically significant improvement in recurrence-free survival in patients who underwent radiotherapy (HR 0.68; 95\% CI 0.49-0.93), but not in patients who underwent radical prostatectomy (HR 1.05; 95\% CI 0.90-1.24) ${ }^{95}$. Taken together, these results suggest statins may slow progression of prostate cancer in men undergoing radiation, possibly by sensitizing the cells to radiotherapy, though further study is needed to confirm these findings. It has been suggested that statin may radio-sensitize prostate tumor cells by causing growth arrest in the late $\mathrm{G}_{1}$, the phase of the cell cycle when cells are most sensitive to radiation-induced cell death ${ }^{96}$. However, some evidence suggests that this association may not be limited to radiotherapy patients. A retrospective study that investigated the effect of statin use after radical prostatectomy on PSA recurrence in a cohort of men that never received statins before surgery found that use of statins was associated with a $36 \%$ reduction in the risk of PSA recurrence ${ }^{97}$. Indeed, a study that examined the association of pre and postoperative use of statins in 2,137 Korean men who underwent radical prostatectomy between 1998 and 2011 at Asan Medical Center found that although preoperative use of statins was not associated with different pathologic outcome, postoperative use of statins enhanced recurrence-free survival especially in patients with high risk disease ${ }^{86}$. Finally, one study reported that statin use significantly prolonged time to progression in 926 men receiving androgen deprivation therapy (ADT), even after adjusting for known prognostic factors such as biopsy Gleason score, type of primary therapy, and presence of metastases at ADT initiation ${ }^{98}$.

Statins have also been evaluated for their ability to reduce common side effects associated with local treatment of prostate cancer. For example, one important side effect is erectile dysfunction. Hong et al., in a randomized controlled trial, prospectively examined the 
effect of statins on recovery of erectile function after radical retropubic prostatectomy in 50 men without hypercholesterolemia who never used statins. The study found that postoperative treatment with a statin was associated with earlier recovery of erectile function as judged by a significantly improved Index of Erectile Function-5 score $(p=0.003)$ in statin users vs. nonusers $^{87}$. This result is in agreement with a recent meta-analysis of 11 prospective randomized clinical trials which found that randomization to statins resulted in a clinically relevant improvement in erectile function even after adjusting for the average age of participants and level of LDL cholesterol, two potential confounding factors ${ }^{88}$.

\section{Moving forward}

Successful completion of the Prostate Cancer Prevention Trial (PCPT), the Reduction by Dutasteride of Prostate Cancer Events (REDUCE), and the Selenium and Vitamin E Cancer Prevention Trial (SELECT) demonstrates that participants can be recruited for large prostate cancer primary prevention trials. Considering mounting evidence that supports a role for statins in reducing prostate cancer risk, especially advanced prostate cancer, do we launch a similar size trial to test the efficacy of statins in the primary prevention of prostate cancer? We strongly believe the short answer is "NOT YET" due to the following reasons. First, from a basic science perspective, our understanding of the many potential mechanisms through which statins may prevent development and progression of cancer is still far from complete. Deciphering these mechanisms will allow us to identify novel anti-cancer pathways that could inform the development of next generation prostate cancer therapeutics as well as help guide appropriate statin clinical trials with intermediate end-points. In addition, understanding the mechanisms linking cholesterol and prostate cancer will lead to the identification of tumor biomarkers indicating response to statins, thus enabling statin therapy to be targeted to patients predicted to 
show a tumor response. Second, it is unclear which type of statin would be most appropriate for use in a clinical trial. However, simvastatin is the most commonly-used statin in the vast majority of epidemiologic studies reporting an inverse association between statin use and risk of advanced prostate cancer, potentially supporting the use of simvastatin in prostate cancer trials. Future epidemiologic studies with sufficient sample size should interrogate the effects of different statin types on prostate cancer risk and progression or, at very least, report the frequency of use of different types of statin in their populations. Finally, two major obstacles to a primary prevention statin trial are readily foreseeable. First, as the prevalence of statin use is so great, it would be a considerable challenge to find eligible non-users who would enroll in such a trial and who would stay in the placebo arm without becoming statin users in later stages. Second, advanced prostate cancer is a relatively rare occurrence at the time of diagnosis in the PSA era. Since statins appear to be most strongly linked with reduced risk of this form of the disease, the number of men that would need to be randomized and the duration of their follow-up required to detect a difference in advanced disease would be vast.

Meanwhile, we feel that much can be learned without the need to launch such an expensive, large and time-consuming primary prevention trial. For example, there is a strong impetus to begin analyzing statins' role in secondary and tertiary prevention; do statins improve outcomes in men already diagnosed with prostate cancer? While statins do not appear to impact risk of localized prostate cancer, epidemiologic evidence supports a role for statins in delaying disease recurrence and reducing prostate cancer-specific mortality regardless of disease characteristics at diagnosis, thereby providing rationale for secondary prevention trials among all prostate cancer patients. Late stage castrate resistant or metastatic prostate cancer is a disease of short duration and outcome events occur in the order of months to a couple of years. 
Accordingly, from an epidemiology standpoint, more meaningful results with much smaller sample sizes and shorter trial durations can be extrapolated from studying the role of statins in this disease stage. Much could be learned about the biology of statins here. Moving earlier in the spectrum of the disease to study men undergoing primary treatment would also yield information about how statins interact with our current treatment modalities and may identify factors that predict response, such as changes in lipid profiles following the start of statins. In men on active surveillance protocols, particularly among those at highest risk of disease progression, statins could be tested as an adjuvant therapy to reduce or delay the need for subsequent treatment and tumour response could be monitored in real-time using tumour imaging ${ }^{99}$ Indeed, targeting highrisk populations has been suggested as a way to maximize risk-benefit ratio by a recent commentary ${ }^{100}$, although statins are well-tolerated drugs with few major side effects. Next generation prostate cancer drugs could be used separately or in combination with statins to reduce prostate cancer mortality and/or morbidity. Clinical trials to interrogate statins in combination with other agents are warranted, particularly those that show synergy in animal models and whose mechanism of synergistic activity is known. Indeed, a recent study that examined the effect of statins and metformin combinations on biochemical recurrence among diabetic men undergoing radical prostatectomy found that although neither statin nor metformin use alone was associated with reduced risk of biochemical recurrence, their interaction led to a significantly lower risk ${ }^{92}$. Other potential candidates for combination treatments are LXR agonists; these agents stimulate cholesterol efflux from cancer cells thus reducing their intracellular cholesterol stores and inducing apoptosis ${ }^{40}$ and thereby may act synergistically with statins to inhibit prostate cancer growth.

\section{Conclusions}


Mounting evidence is emerging from the current literature to support that statin use may be associated with a lower risk of advanced prostate cancer. While it is difficult to determine causality from observational studies, these epidemiological data are also supported by a plethora of preclinical studies showing that statins directly inhibit prostate cancer development and progression in cell-based and animal-based models. Thus, there is ample justification to proceed with further population-based and basic research, and the results from these studies will bolster current rationale for a primary prevention trial as well as targeted clinical trials with mechanistic end-points. At present, we still need more data regarding the "benefits" of statins before we can advocate that all men at risk of prostate cancer start statins regardless of their cholesterol profile. However, the use of statins in secondary and tertiary prevention to improve therapeutic outcomes for men already diagnosed with prostate cancer may be realized in the not too distant future. 


\section{References}

1. Wong, N.D., Lopez, V., Tang, S. \& Williams, G.R. Prevalence, treatment, and control of combined hypertension and hypercholesterolemia in the United States. Am J Cardiol 98, 204-8 (2006).

2. Gu Q, P.-R.R., Burt VL, Kit BK. Prescription cholesterol-lowering medication use in adults aged 40 and over: United States, 2003-2012. NCHS data brief, no 177. Hyattsville, MD: National Center for Health Statistics. (2014).

3. Baigent, C. et al. Efficacy and safety of cholesterol-lowering treatment: prospective metaanalysis of data from 90,056 participants in 14 randomised trials of statins. Lancet $\mathbf{3 6 6}$, 1267-78 (2005).

4. Poynter, J.N. et al. Statins and the risk of colorectal cancer. $N$ Engl J Med 352, 2184-92 (2005).

5. Friis, S. et al. Cancer risk among statin users: a population-based cohort study. Int J Cancer 114, 643-7 (2005).

6. Shannon, J. et al. Statins and prostate cancer risk: a case-control study. Am J Epidemiol 162, 318-25 (2005).

7. Graaf, M.R., Beiderbeck, A.B., Egberts, A.C., Richel, D.J. \& Guchelaar, H.J. The risk of cancer in users of statins. J Clin Oncol 22, 2388-94 (2004).

8. Platz, E.A. et al. Statin drugs and risk of advanced prostate cancer. J Natl Cancer Inst 98, 1819-25 (2006).

9. Jacobs, E.J. et al. Cholesterol-lowering drugs and advanced prostate cancer incidence in a large U.S. cohort. Cancer Epidemiol Biomarkers Prev 16, 2213-7 (2007). 
10. Murtola, T.J., Tammela, T.L., Lahtela, J. \& Auvinen, A. Cholesterol-lowering drugs and prostate cancer risk: a population-based case-control study. Cancer Epidemiol Biomarkers Prev 16, 2226-32 (2007).

11. Flick, E.D. et al. Statin use and risk of prostate cancer in the California Men's Health Study cohort. Cancer Epidemiol Biomarkers Prev 16, 2218-25 (2007).

12. Dale, K.M., Coleman, C.I., Henyan, N.N., Kluger, J. \& White, C.M. Statins and cancer risk: a meta-analysis. JAMA 295, 74-80 (2006).

13. Browning, D.R. \& Martin, R.M. Statins and risk of cancer: a systematic review and metaanalysis. Int J Cancer 120, 833-43 (2007).

14. Zakikhani, M., Dowling, R., Fantus, I.G., Sonenberg, N. \& Pollak, M. Metformin is an AMP kinase-dependent growth inhibitor for breast cancer cells. Cancer Res 66, 10269-73 (2006).

15. Agalliu, I., Salinas, C.A., Hansten, P.D., Ostrander, E.A. \& Stanford, J.L. Statin use and risk of prostate cancer: results from a population-based epidemiologic study. Am $J$ Epidemiol 168, 250-60 (2008).

16. Boudreau, D.M., Yu, O., Buist, D.S. \& Miglioretti, D.L. Statin use and prostate cancer risk in a large population-based setting. Cancer Causes Control 19, 767-74 (2008).

17. Jespersen, C.G., Norgaard, M., Friis, S., Skriver, C. \& Borre, M. Statin use and risk of prostate cancer: a Danish population-based case-control study, 1997-2010. Cancer Epidemiol 38, $42-7$ (2014).

18. Kashani, A. et al. Risks associated with statin therapy: a systematic overview of randomized clinical trials. Circulation 114, 2788-97 (2006). 
19. Sattar, N. et al. Statins and risk of incident diabetes: a collaborative meta-analysis of randomised statin trials. Lancet $\mathbf{3 7 5}, 735-42$ (2010).

20. Carroll, M.D., Kit, B.K., Lacher, D.A., Shero, S.T. \& Mussolino, M.E. Trends in lipids and lipoproteins in US adults, 1988-2010. JAMA 308, 1545-54 (2012).

21. Siegel, D., Lopez, J. \& Meier, J. Use of cholesterol-lowering medications in the United States from 1991 to 1997. Am J Med 108, 496-9 (2000).

22. LaRosa, J.C. Pleiotropic effects of statins and their clinical significance. Am J Cardiol 88, 291-3 (2001).

23. Youssef, S. et al. The HMG-CoA reductase inhibitor, atorvastatin, promotes a Th2 bias and reverses paralysis in central nervous system autoimmune disease. Nature 420, 78-84 (2002).

24. Weis, M., Heeschen, C., Glassford, A.J. \& Cooke, J.P. Statins have biphasic effects on angiogenesis. Circulation 105, 739-45 (2002).

25. Rao, S. et al. Lovastatin-mediated G1 arrest is through inhibition of the proteasome, independent of hydroxymethyl glutaryl-CoA reductase. Proc Natl Acad Sci U S A 96, 7797802 (1999).

26. Nubel, T., Dippold, W., Kleinert, H., Kaina, B. \& Fritz, G. Lovastatin inhibits Rhoregulated expression of E-selectin by TNFalpha and attenuates tumor cell adhesion. FASEB $J$ 18, 140-2 (2004).

27. Brown, M. et al. The differential effects of statins on the metastatic behaviour of prostate cancer. Br J Cancer 106, 1689-96 (2012).

28. Hoque, A., Chen, H. \& Xu, X.C. Statin induces apoptosis and cell growth arrest in prostate cancer cells. Cancer Epidemiol Biomarkers Prev 17, 88-94 (2008). 
29. Demierre, M.F., Higgins, P.D., Gruber, S.B., Hawk, E. \& Lippman, S.M. Statins and cancer prevention. Nat Rev Cancer 5, 930-42 (2005).

30. Schaffner, C.P. Prostatic cholesterol metabolism: regulation and alteration. Prog Clin Biol Res 75A, 279-324 (1981).

31. Lee, B.H. et al. Dysregulation of cholesterol homeostasis in human prostate cancer through loss of ABCA1. Cancer Res 73, 1211-8 (2013).

32. Porstmann, T. et al. SREBP activity is regulated by mTORC1 and contributes to Aktdependent cell growth. Cell Metab 8, 224-36 (2008).

33. Yue, S. et al. Cholesteryl ester accumulation induced by PTEN loss and PI3K/AKT activation underlies human prostate cancer aggressiveness. Cell Metab 19, 393-406 (2014).

34. Simons, K. \& Ikonen, E. Functional rafts in cell membranes. Nature 387, 569-72 (1997).

35. Freeman, M.R., Cinar, B. \& Lu, M.L. Membrane rafts as potential sites of nongenomic hormonal signaling in prostate cancer. Trends Endocrinol Metab 16, 273-9 (2005).

36. Zhuang, L., Lin, J., Lu, M.L., Solomon, K.R. \& Freeman, M.R. Cholesterol-rich lipid rafts mediate akt-regulated survival in prostate cancer cells. Cancer Res 62, 2227-31 (2002).

37. Smith, S.M. et al. Luteinizing hormone receptors translocate to plasma membrane microdomains after binding of human chorionic gonadotropin. Endocrinology 147, 178995 (2006).

38. Lawrence, J.C., Saslowsky, D.E., Edwardson, J.M. \& Henderson, R.M. Real-time analysis of the effects of cholesterol on lipid raft behavior using atomic force microscopy. Biophys $J$ 84, 1827-32 (2003).

39. Toren, P. \& Zoubeidi, A. Targeting the PI3K/Akt pathway in prostate cancer: challenges and opportunities (review). Int J Oncol 45, 1793-801 (2014). 
40. Pommier, A.J. et al. Liver X Receptor activation downregulates AKT survival signaling in lipid rafts and induces apoptosis of prostate cancer cells. Oncogene 29, 2712-23 (2010).

41. Horinaga, M. et al. Clinical and pathologic significance of activation of signal transducer and activator of transcription 3 in prostate cancer. Urology 66, 671-5 (2005).

42. Zhuang, L., Kim, J., Adam, R.M., Solomon, K.R. \& Freeman, M.R. Cholesterol targeting alters lipid raft composition and cell survival in prostate cancer cells and xenografts. J Clin Invest 115, 959-68 (2005).

43. Dobs, A.S. et al. Effects of high-dose simvastatin on adrenal and gonadal steroidogenesis in men with hypercholesterolemia. Metabolism 49, 1234-8 (2000).

44. Hyyppa, M.T., Kronholm, E., Virtanen, A., Leino, A. \& Jula, A. Does simvastatin affect mood and steroid hormone levels in hypercholesterolemic men? A randomized doubleblind trial. Psychoneuroendocrinology 28, 181-94 (2003).

45. Smals, A.G., Weusten, J.J., Benraad, T.J. \& Kloppenborg, P.W. The HMG-CoA reductase inhibitor simvastatin suppresses human testicular testosterone synthesis in vitro by a selective inhibitory effect on 17-ketosteroid-oxidoreductase enzyme activity. J Steroid Biochem Mol Biol 38, 465-8 (1991).

46. Segarra, A., Chacon, P., Vilardell, M. \& Piera, L.L. Prospective case control study to determine the effect of lovastatin on serum testosterone and cortisol concentrations in hyperlipidemic nephrotic patients with chronic renal failure. Nephron 73, 186-90 (1996).

47. Bernini, G.P. et al. Effects of long-term simvastatin treatment on testicular and adrenal steroidogenesis in hypercholesterolemic patients. J Endocrinol Invest 17, 227-33 (1994).

48. Bohm, M., Herrmann, W., Wassmann, S., Laufs, U. \& Nickenig, G. Does statin therapy influence steroid hormone synthesis? Z Kardiol 93, 43-8 (2004). 
49. Dobs, A.S. et al. Effects of simvastatin and pravastatin on gonadal function in male hypercholesterolemic patients. Metabolism 49, 115-21 (2000).

50. Hall, S.A. et al. Do statins affect androgen levels in men? Results from the Boston area community health survey. Cancer Epidemiol Biomarkers Prev 16, 1587-94 (2007).

51. Mohler, J.L. et al. The androgen axis in recurrent prostate cancer. Clin Cancer Res 10, 4408 (2004).

52. Page, S.T. et al. Persistent intraprostatic androgen concentrations after medical castration in healthy men. J Clin Endocrinol Metab 91, 3850-6 (2006).

53. Pelletier, G., Luu-The, V., El-Alfy, M., Li, S. \& Labrie, F. Immunoelectron microscopic localization of 3beta-hydroxysteroid dehydrogenase and type 5 17beta-hydroxysteroid dehydrogenase in the human prostate and mammary gland. J Mol Endocrinol 26, 11-9 (2001).

54. Mostaghel, E.A., Solomon, K.R., Pelton, K., Freeman, M.R. \& Montgomery, R.B. Impact of circulating cholesterol levels on growth and intratumoral androgen concentration of prostate tumors. PLoS One 7, e30062 (2012).

55. Graaf, M.R., Richel, D.J., van Noorden, C.J. \& Guchelaar, H.J. Effects of statins and farnesyltransferase inhibitors on the development and progression of cancer. Cancer Treat Rev 30, 609-41 (2004).

56. Weber, M.J. \& Gioeli, D. Ras signaling in prostate cancer progression. J Cell Biochem $\mathbf{9 1 ,}$ $13-25$ (2004).

57. Lee, S.J. et al. Inhibition of the 3-hydroxy-3-methylglutaryl-coenzyme A reductase pathway induces p53-independent transcriptional regulation of $\mathrm{p} 21(\mathrm{WAF} 1 / \mathrm{CIP} 1)$ in human prostate carcinoma cells. J Biol Chem 273, 10618-23 (1998). 
58. Marcelli, M. et al. Caspase-7 is activated during lovastatin-induced apoptosis of the prostate cancer cell line LNCaP. Cancer Res 58, 76-83 (1998).

59. Banez, L.L. et al. Association between statins and prostate tumor inflammatory infiltrate in men undergoing radical prostatectomy. Cancer Epidemiol Biomarkers Prev 19, 722-8 (2010).

60. Mucci, L.A. \& Stampfer, M.J. Mounting evidence for prediagnostic use of statins in reducing risk of lethal prostate cancer. J Clin Oncol 32, 1-2 (2014).

61. Society, A.C. Cancer Facts \& Figures 2015. Atlanta; American Cancer Society (2015).

62. Blais, L., Desgagne, A. \& LeLorier, J. 3-Hydroxy-3-methylglutaryl coenzyme A reductase inhibitors and the risk of cancer: a nested case-control study. Arch Intern Med 160, 23638 (2000).

63. Kaye, J.A. \& Jick, H. Statin use and cancer risk in the General Practice Research Database. Br J Cancer 90, 635-7 (2004).

64. Coogan, P.F., Kelly, J.P., Strom, B.L. \& Rosenberg, L. Statin and NSAID use and prostate cancer risk. Pharmacoepidemiol Drug Saf 19, 752-5 (2010).

65. Chang, C.C., Ho, S.C., Chiu, H.F. \& Yang, C.Y. Statins increase the risk of prostate cancer: a population-based case-control study. Prostate 71, 1818-24 (2011).

66. Haukka, J. et al. Incidence of cancer and statin usage--record linkage study. Int J Cancer 126, 279-84 (2010).

67. Farwell, W.R., D'Avolio, L.W., Scranton, R.E., Lawler, E.V. \& Gaziano, J.M. Statins and prostate cancer diagnosis and grade in a veterans population. J Natl Cancer Inst 103, 885$92(2011)$. 
68. Murtola, T.J. et al. Prostate cancer and PSA among statin users in the Finnish prostate cancer screening trial. Int J Cancer 127, 1650-9 (2010).

69. Breau, R.H. et al. The association between statin use and the diagnosis of prostate cancer in a population based cohort. J Urol 184, 494-9 (2010).

70. Tan, N., Klein, E.A., Li, J., Moussa, A.S. \& Jones, J.S. Statin use and risk of prostate cancer in a population of men who underwent biopsy. J Urol 186, 86-90 (2011).

71. Lustman, A., Nakar, S., Cohen, A.D. \& Vinker, S. Statin use and incident prostate cancer risk: does the statin brand matter? A population-based cohort study. Prostate Cancer Prostatic Dis 17, 6-9 (2014).

72. Morote, J. et al. Role of serum cholesterol and statin use in the risk of prostate cancer detection and tumor aggressiveness. Int J Mol Sci 15, 13615-23 (2014).

73. Kantor, E.D. et al. Statin use and risk of prostate cancer: Results from the Southern Community Cohort Study. Prostate 75, 1384-93 (2015).

74. Freedland, S.J. et al. Statin use and risk of prostate cancer and high-grade prostate cancer: results from the REDUCE study. Prostate Cancer Prostatic Dis 16, 254-9 (2013).

75. Smeeth, L., Douglas, I., Hall, A.J., Hubbard, R. \& Evans, S. Effect of statins on a wide range of health outcomes: a cohort study validated by comparison with randomized trials. Br J Clin Pharmacol 67, 99-109 (2009).

76. Hippisley-Cox, J. \& Coupland, C. Unintended effects of statins in men and women in England and Wales: population based cohort study using the QResearch database. BMJ 340, c2197 (2010). 
77. Jacobs, E.J., Newton, C.C., Thun, M.J. \& Gapstur, S.M. Long-term use of cholesterollowering drugs and cancer incidence in a large United States cohort. Cancer Res 71, 1763$71(2011)$.

78. Chan, J.M. et al. Statin use and risk of prostate cancer in the prospective Osteoporotic Fractures in Men (MrOS) Study. Cancer Epidemiol Biomarkers Prev 21, 1886-8 (2012).

79. Bansal, D., Undela, K., D'Cruz, S. \& Schifano, F. Statin use and risk of prostate cancer: a meta-analysis of observational studies. PLoS One 7, e46691 (2012).

80. Cholesterol Treatment Trialists, C. et al. Efficacy and safety of LDL-lowering therapy among men and women: meta-analysis of individual data from 174,000 participants in 27 randomised trials. Lancet 385, 1397-405 (2015).

81. Bonovas, S., Filioussi, K. \& Sitaras, N.M. Statin use and the risk of prostate cancer: A metaanalysis of 6 randomized clinical trials and 13 observational studies. Int J Cancer 123, 899-904 (2008).

82. Kuoppala, J., Lamminpaa, A. \& Pukkala, E. Statins and cancer: A systematic review and meta-analysis. Eur J Cancer 44, 2122-32 (2008).

83. Solomon, K.R. \& Freeman, M.R. The complex interplay between cholesterol and prostate malignancy. Urol Clin North Am 38, 243-59 (2011).

84. Friedman, G.D. et al. Screening statins for possible carcinogenic risk: up to 9 years of follow-up of 361,859 recipients. Pharmacoepidemiol Drug Saf 17, 27-36 (2008).

85. Geybels, M.S. et al. Statin use in relation to prostate cancer outcomes in a population-based patient cohort study. Prostate 73, 1214-22 (2013).

86. Nielsen, S.F., Nordestgaard, B.G. \& Bojesen, S.E. Statin use and reduced cancer-related mortality. N Engl J Med 367, 1792-802 (2012). 
87. Grytli, H.H., Fagerland, M.W., Fossa, S.D. \& Tasken, K.A. Association between use of beta-blockers and prostate cancer-specific survival: a cohort study of 3561 prostate cancer patients with high-risk or metastatic disease. Eur Urol 65, 635-41 (2014).

88. Yu, O. et al. Use of statins and the risk of death in patients with prostate cancer. J Clin Oncol 32, 5-11 (2014).

89. Cyrus-David, M.S., Weinberg, A., Thompson, T. \& Kadmon, D. The effect of statins on serum prostate specific antigen levels in a cohort of airline pilots: a preliminary report. $J$ Urol 173, 1923-5 (2005).

90. Shi, Y. et al. Statin medications are associated with a lower probability of having an abnormal screening prostate-specific antigen result. Urology 84, 1058-65 (2014).

91. Chang, S.L., Harshman, L.C. \& Presti, J.C., Jr. Impact of common medications on serum total prostate-specific antigen levels: analysis of the National Health and Nutrition Examination Survey. J Clin Oncol 28, 3951-7 (2010).

92. Allott, E.H. et al. Statin use and prostate cancer aggressiveness: results from the population-based North Carolina-Louisiana Prostate Cancer Project. Cancer Epidemiol Biomarkers Prev (2016).

93. Mondul, A.M., Caffo, B. \& Platz, E.A. Minimal detection bias in the inverse association between statin drug use and advanced prostate cancer risk: a simulation study. Cancer Epidemiol 35, e6-11 (2011).

94. Ciatto, S. et al. Contamination by opportunistic screening in the European Randomized Study of Prostate Cancer Screening. BJU Int 92 Suppl 2, 97-100 (2003).

95. Park, H.S. et al. Statins and prostate cancer recurrence following radical prostatectomy or radiotherapy: a systematic review and meta-analysis. Ann Oncol 24, 1427-34 (2013). 
96. Chan, K.K., Oza, A.M. \& Siu, L.L. The statins as anticancer agents. Clin Cancer Res 9, 10-9 (2003).

97. Allott, E.H. et al. Postoperative statin use and risk of biochemical recurrence following radical prostatectomy: results from the Shared Equal Access Regional Cancer Hospital (SEARCH) database. BJU Int (2014).

98. Harshman, L.C. et al. Statin Use at the Time of Initiation of Androgen Deprivation Therapy and Time to Progression in Patients With Hormone-Sensitive Prostate Cancer. JAMA Oncol 1, 495-504 (2015).

99. Futterer, J.J. et al. Can Clinically Significant Prostate Cancer Be Detected with Multiparametric Magnetic Resonance Imaging? A Systematic Review of the Literature. Eur Urol 68, 1045-53 (2015).

100. Meyskens, F.L., Jr. et al. Cancer Prevention: Obstacles, Challenges and the Road Ahead. J Natl Cancer Inst 108 (2016).

101. Siegel, R.L., Miller, K.D. \& Jemal, A. Cancer statistics, 2015. CA Cancer J Clin 65, 5-29 (2015).

102. Gazzerro, P. et al. Pharmacological actions of statins: a critical appraisal in the management of cancer. Pharmacol Rev 64, 102-46 (2012).

103. McKenney, J.M. Pharmacologic characteristics of statins. Clin Cardiol 26, III32-8 (2003). 


\section{Figure legends}

Figure 1: US prostate cancer-specific mortality rate ${ }^{101}$, prevalence of high cholesterol in US

males over 20 years of age ${ }^{20}$, prevalence of statin use in US males over 40 years of age ${ }^{2}$, and year of Federal Drug Administration (FDA) approval in the US for each type of statin.

Figure 2: Cholesterol-mediated and non-cholesterol-mediated mechanisms contributing to the association between statin use and prostate cancer.

Figure 3: Natural history of prostate cancer, with arrows indicating the stages of prostate cancer at which observational studies have demonstrated statins may play a protective role; 1) clinical manifestation of advanced prostate cancer, 2) biochemical recurrence after primary therapy, and 3) development of castrate resistance (CRPC) after androgen deprivation therapy, leading to 4) prostate cancer death. 
Table 1: Pharmacologic characteristics of statin medications ${ }^{2,102,103}$

\begin{tabular}{l|cccc} 
Statin type & $\begin{array}{c}\text { Frequency of } \\
\text { use (\%) in US } \\
\text { statin users, } \\
2011-12\end{array}$ & Solubility & $\begin{array}{c}\mathrm{IC}_{50}(\mathrm{nM}) \text { for HMG- } \\
\text { CoA reductase } \\
\text { inhibition }\end{array}$ & $\begin{array}{c}\text { Systemic } \\
\text { bioavailability } \\
(\%)\end{array}$ \\
\hline Simvastatin & 42.0 & Lipophilic & 11.2 & $<5$ \\
Atorvastatin & 20.2 & Lipophilic & 8.2 & $\sim 14$ \\
Pravastatin & 11.2 & Hydrophilic & 44.1 & 17 \\
Rosuvastatin & 8.2 & Hydrophilic & 5.4 & $\sim 20$ \\
Lovastatin & 7.4 & Lipophilic & $2.7-11.1$ & $<5$ \\
Pitavastatin & $\mathrm{NR}$ & Lipophilic & 6.8 & $>60$ \\
Fluvastatin & $\mathrm{NR}$ & Lipophilic & 27.6 & 24
\end{tabular}

HMG-CoA reductase $=3$-hydroxy-3-methylglutaryl coenzyme A reductase; $\mathrm{IC}_{50}=$ half maximal inhibitory concentration; $\mathrm{NR}=$ not reported 
Table 2: Observational studies of statin use and prostate cancer risk

\begin{tabular}{|c|c|c|c|c|c|c|c|}
\hline Study & Design & Country & $\begin{array}{l}\text { Number of } \\
\text { subjects }\end{array}$ & Statin type & $\begin{array}{l}\text { Follow } \\
\text { up* }\end{array}$ & $\begin{array}{l}\text { Exposure } \\
\text { definition for } \\
\text { primary } \\
\text { analysis }\end{array}$ & $\begin{array}{l}\text { Fully adjusted results for total and } \\
\text { advanced prostate cancer }\end{array}$ \\
\hline $\begin{array}{l}\text { Blais et } \\
\text { al., } 2000\end{array}$ & $\begin{array}{l}\text { Population- } \\
\text { based nested } \\
\text { case-control }\end{array}$ & Canada & $\begin{array}{l}780 \text { controls; } \\
78 \text { cases }\end{array}$ & NR & $\begin{array}{l}\text { Median } \\
2.7 \\
\text { years }\end{array}$ & $\begin{array}{l}\text { Statin use vs. } \\
\text { use of bile } \\
\text { acid-binding } \\
\text { resins }\end{array}$ & Total: RR 0.74 (95\% CI 0.36-1.51) \\
\hline $\begin{array}{l}\text { Graaf et } \\
\text { al., } 2004\end{array}$ & $\begin{array}{l}\text { Population- } \\
\text { based nested } \\
\text { case-control }\end{array}$ & $\begin{array}{l}\text { Nether- } \\
\text { lands }\end{array}$ & $\begin{array}{l}16,976 \\
\text { controls; } 186 \\
\text { cases }\end{array}$ & $\begin{array}{l}80 \% \\
\text { simvastatin } \\
; 7 \% \\
\text { pravastatin }\end{array}$ & $\begin{array}{l}\text { Mean } \\
7.2 \\
\text { years }\end{array}$ & $\begin{array}{l}\text { Statin use vs. } \\
\text { nonuse }\end{array}$ & Total: OR 0.37 (95\% CI 0.11-1.25) \\
\hline $\begin{array}{l}\text { Kaye } e t \\
a l ., 2004\end{array}$ & Case-control & UK & $\begin{array}{l}7,451 \\
\text { controls; } 569 \\
\text { cases }\end{array}$ & NR & - & $\begin{array}{l}\text { Current statin } \\
\text { use vs. nonuse } \\
\text { (in men } \\
\text { without hyper- } \\
\text { lipidemia) }\end{array}$ & Total: RR 1.3 (95\% CI 1.0-1.9) \\
\hline $\begin{array}{l}\text { Friis } e t \\
\text { al., } 2005\end{array}$ & $\begin{array}{l}\text { Population- } \\
\text { based cohort }\end{array}$ & Denmark & $\begin{array}{l}168,133 \text { men; } \\
1,626 \text { cases }\end{array}$ & $\begin{array}{l}\text { Majority } \\
\text { simvastatin }\end{array}$ & $\begin{array}{l}\text { Mean } 4 \\
\text { years }\end{array}$ & $\begin{array}{l}\text { Statin use vs. } \\
\text { nonuse }\end{array}$ & Total: RR 0.87 (95\% CI 0.61-1.23) \\
\hline $\begin{array}{l}\text { Shannon } \\
\text { et al., } \\
2005\end{array}$ & $\begin{array}{l}\text { Hospital- } \\
\text { based case } \\
\text { control }\end{array}$ & US & $\begin{array}{l}202 \text { controls; } \\
100 \text { cases ( } 57 \\
\text { advanced) }\end{array}$ & $\begin{array}{l}>97 \% \\
\text { simvastatin } \\
\text { or } \\
\text { lovastatin }\end{array}$ & - & $\begin{array}{l}\text { Statin use vs. } \\
\text { nonuse }\end{array}$ & $\begin{array}{l}\text { Total: OR } 0.35 \text { (95\% CI 0.20-0.64) } \\
\text { Advanced }^{\mathrm{a}} \text { : OR } 0.24 \text { (95\% CI 0.11-0.53) }\end{array}$ \\
\hline $\begin{array}{l}\text { Platz et } \\
\text { al., } 2006\end{array}$ & $\begin{array}{l}\text { Prospective } \\
\text { cohort }\end{array}$ & US & $\begin{array}{l}34,989 \text { men; } \\
2,579 \text { cases } \\
(316 \\
\text { advanced })\end{array}$ & NR & $\begin{array}{l}376,939 \\
\text { person- } \\
\text { years }\end{array}$ & $\begin{array}{l}\text { Current statin } \\
\text { use vs. } \\
\text { never/past } \\
\text { statin use }\end{array}$ & $\begin{array}{l}\text { Total: RR } 0.96 \text { (95\% CI 0.85-1.09) } \\
\text { Advanced }^{\mathbf{b}} \text { : RR } 0.51 \text { (95\% CI 0.30-0.86) }\end{array}$ \\
\hline $\begin{array}{l}\text { Flick et } \\
\text { al., } \\
2007\end{array}$ & $\begin{array}{l}\text { Prospective } \\
\text { cohort }\end{array}$ & US & $\begin{array}{l}69,047 \text { men; } \\
888 \text { cases } \\
(131 \\
\text { advanced })\end{array}$ & $\begin{array}{l}64 \% \\
\text { lovastatin; } \\
30 \% \\
\text { simvastatin }\end{array}$ & $\begin{array}{l}\text { Median } \\
2.3 \\
\text { years }\end{array}$ & $\begin{array}{l}\text { Statin use vs. } \\
\text { nonuse }\end{array}$ & $\begin{array}{l}\text { Total: RR } 0.92 \text { (95\% CI 0.79-1.07) } \\
\text { Advanced }^{c}: \text { RR } 0.80 \text { (95\% CI 0.53-1.19) }\end{array}$ \\
\hline $\begin{array}{l}\text { Jacobs et } \\
\text { al., } 2007\end{array}$ & $\begin{array}{l}\text { Prospective } \\
\text { cohort }\end{array}$ & US & $\begin{array}{l}55,454 \text { men; } \\
3,413 \text { cases } \\
(317 \\
\text { advanced })\end{array}$ & NR & NR & $\begin{array}{l}\text { Long-term } \\
\text { statin use }(\geq 5 \\
\text { years }) \text { vs. } \\
\text { nonuse }\end{array}$ & $\begin{array}{l}\text { Total: RR } 1.06 \text { (95\% CI 0.93-1.20) } \\
\text { Advanced }^{\text {d: }} \text { RR } 0.60 \text { (95\% CI 0.36-1.00) }\end{array}$ \\
\hline $\begin{array}{l}\text { Murtola et } \\
\text { al., } 2007\end{array}$ & $\begin{array}{l}\text { Population- } \\
\text { based case } \\
\text { control }\end{array}$ & Finland & $\begin{array}{l}24,723 \text { case } \\
\text { control pairs } \\
(\sim 3,700 \\
\text { advanced })\end{array}$ & $\begin{array}{l}\sim 50 \% \\
\text { simvastatin } \\
, \sim 25 \% \\
\text { atorvastatin } \\
, \sim 20 \% \\
\text { fluvastatin, } \\
\sim 20 \% \\
\text { lovastatin }\end{array}$ & - & $\begin{array}{l}\text { Statin use vs. } \\
\text { nonuse }\end{array}$ & 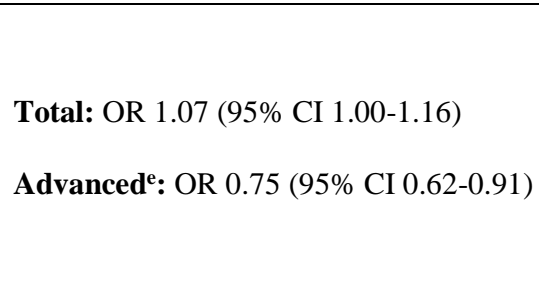 \\
\hline $\begin{array}{l}\text { Agalliu et } \\
\text { al., } 2008\end{array}$ & $\begin{array}{l}\text { Population- } \\
\text { based case- } \\
\text { control }\end{array}$ & US & $\begin{array}{l}942 \text { controls; } \\
1,001 \text { cases } \\
\text { (181 } \\
\text { advanced })\end{array}$ & $\begin{array}{l}\sim 20 \% \\
\text { atorvastatin } \\
\sim 9 \% \\
\text { simvastatin }\end{array}$ & - & $\begin{array}{l}\text { Statin use vs. } \\
\text { nonuse }\end{array}$ & 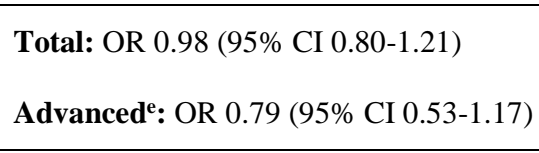 \\
\hline $\begin{array}{l}\text { Boudreau } \\
\text { et al., } \\
2008\end{array}$ & $\begin{array}{l}\text { Retrospectiv } \\
\text { e cohort }\end{array}$ & US & $\begin{array}{l}83,372 \text { men; } \\
2,532 \text { cases } \\
\text { (740 } \\
\text { advanced) }\end{array}$ & $\begin{array}{l}\text { Majority } \\
\text { lovastatin } \\
\text { and } \\
\text { simvastatin }\end{array}$ & $\begin{array}{l}\text { Median } \\
5.7 \\
\text { years }\end{array}$ & $\begin{array}{l}\text { Statin use vs. } \\
\text { nonuse }\end{array}$ & 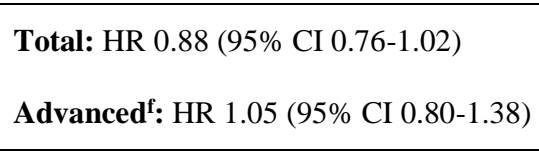 \\
\hline $\begin{array}{l}\text { Friedman } \\
\text { et al., } \\
2008\end{array}$ & $\begin{array}{l}\text { Prospective } \\
\text { cohort }\end{array}$ & US & $\begin{array}{l}2,097,474 \\
\text { men; } 1,706 \\
\text { cases }(217 \\
\text { advanced) } \\
\end{array}$ & $\begin{array}{l}66 \% \\
\text { lovastatin, } \\
29 \% \\
\text { simvastatin }\end{array}$ & $\begin{array}{l}\text { Median } \\
4.9 \\
\text { years }\end{array}$ & $\begin{array}{l}\text { Statin use vs. } \\
\text { nonuse }\end{array}$ & 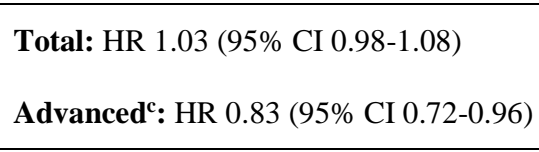 \\
\hline $\begin{array}{l}\text { Smeeth et } \\
\text { al., } 2009\end{array}$ & $\begin{array}{l}\text { Prospective } \\
\text { cohort }\end{array}$ & UK & $\begin{array}{l}364,675 \text { men; } \\
3,525 \text { cases }\end{array}$ & $\begin{array}{l}>50 \% \\
\text { simvastatin } \\
\text { or } \\
\text { atorvastatin }\end{array}$ & $\begin{array}{l}\text { Median } \\
4.4 \\
\text { years }\end{array}$ & $\begin{array}{l}\text { Statin use vs. } \\
\text { nonuse }\end{array}$ & Total: HR 1.06 (95\% CI 0.86-1.30) \\
\hline $\begin{array}{l}\text { Breau et } \\
\text { al., } 2010\end{array}$ & $\begin{array}{l}\text { Prospective } \\
\text { cohort }\end{array}$ & US & $\begin{array}{l}2,447 \text { men; } \\
224 \text { cases }(56 \\
\text { advanced) }\end{array}$ & NR & $\begin{array}{l}\text { Median } \\
15 \text { years }\end{array}$ & $\begin{array}{l}\text { Daily statin use } \\
\text { vs. nonuse }\end{array}$ & $\begin{array}{l}\text { Total: HR } 0.36 \text { (95\% CI 0.25-0.53) } \\
\text { Advanced }^{\mathrm{a}} \text { : HR } 0.25 \text { (95\% CI 0.11-0.58) }\end{array}$ \\
\hline $\begin{array}{l}\text { Coogan et } \\
\text { al., } 2010\end{array}$ & $\begin{array}{l}\text { Hospital- } \\
\text { based case } \\
\text { control }\end{array}$ & US & $\begin{array}{l}2,007 \\
\text { controls; } \\
1,367 \text { cases }\end{array}$ & $\begin{array}{l}\text { Majority } \\
\text { lipophilic }\end{array}$ & - & $\begin{array}{l}\text { Statin use vs. } \\
\text { nonuse }\end{array}$ & 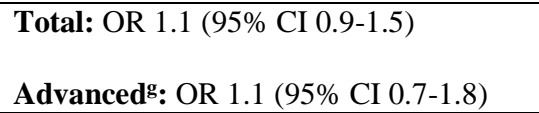 \\
\hline
\end{tabular}




\begin{tabular}{|c|c|c|c|c|c|c|c|}
\hline & & & $\begin{array}{l}\text { (\# advanced } \\
\text { NR) }\end{array}$ & & & & \\
\hline $\begin{array}{l}\text { Haukka } e t \\
\text { al., } 2010\end{array}$ & $\begin{array}{l}\text { Population- } \\
\text { based nested } \\
\text { case control }\end{array}$ & Finland & $\begin{array}{l}235,830 \\
\text { statin } \\
\text { user/non-user } \\
\text { pairs (\# cases } \\
\text { NR) }\end{array}$ & $\begin{array}{l}53 \% \\
\text { simvastatin } \\
, 39 \% \\
\text { atorvastatin }\end{array}$ & $\begin{array}{l}\text { Mean } \\
8.8 \\
\text { years }\end{array}$ & $\begin{array}{l}\text { Statin use vs. } \\
\text { nonuse }\end{array}$ & Total: RR 1.12 (95\% CI 1.08-1.17) \\
\hline $\begin{array}{l}\text { Hippisley- } \\
\text { Cox et al., } \\
2010\end{array}$ & $\begin{array}{l}\text { Prospective } \\
\text { cohort }\end{array}$ & UK & $\begin{array}{l}990,495 \text { men; } \\
7,129 \text { cases }\end{array}$ & $\begin{array}{l}71 \% \\
\text { simvastatin } \\
, 22 \% \\
\text { atorvastatin }\end{array}$ & NR & $\begin{array}{l}\text { Statin use vs. } \\
\text { nonuse }\end{array}$ & Total: HR 1.05 (95\% CI 0.98-1.13) \\
\hline $\begin{array}{l}\text { Murtola et } \\
\text { al., } 2010\end{array}$ & $\begin{array}{l}\text { Prospective } \\
\text { cohort }\end{array}$ & Finland & $\begin{array}{l}23,320 \text { men; } \\
1,594 \text { cases } \\
(133 \\
\text { advanced })\end{array}$ & $\begin{array}{l}45 \% \\
\text { simvastatin } \\
, 41 \% \\
\text { atorvastatin } \\
\end{array}$ & $\begin{array}{l}\text { Median } \\
6.9 \\
\text { years }\end{array}$ & $\begin{array}{l}\text { Statin use vs. } \\
\text { nonuse }\end{array}$ & $\begin{array}{l}\text { Total: HR } 0.75 \text { (95\% CI 0.63-0.89) } \\
\text { Advanced }^{\text {h }: ~ H R ~} 0.93 \text { (95\% CI 0.54-1.58) }\end{array}$ \\
\hline $\begin{array}{l}\text { Chang et } \\
\text { al., } 2011\end{array}$ & $\begin{array}{l}\text { Population- } \\
\text { based case } \\
\text { control }\end{array}$ & Taiwan & $\begin{array}{l}1,552 \\
\text { controls; } 388 \\
\text { cases }\end{array}$ & NR & - & $\begin{array}{l}\text { Statin use vs. } \\
\text { nonuse }\end{array}$ & Total: OR 1.55 (95\% CI 1.09-2.19) \\
\hline $\begin{array}{l}\text { Farwell et } \\
\text { al., } 2011\end{array}$ & $\begin{array}{l}\text { Retrospectiv } \\
\text { e cohort }\end{array}$ & US & $\begin{array}{l}55,875 \text { men; } \\
546 \text { cases } \\
(130 \\
\text { advanced })\end{array}$ & $\begin{array}{l}55 \% \\
\text { simvastatin } \\
, 44 \% \\
\text { lovastatin } \\
\end{array}$ & $\begin{array}{l}\text { Median } \\
5.6 \\
\text { years }\end{array}$ & $\begin{array}{l}\text { Statin use vs. } \\
\text { hypertensive } \\
\text { medication use }\end{array}$ & 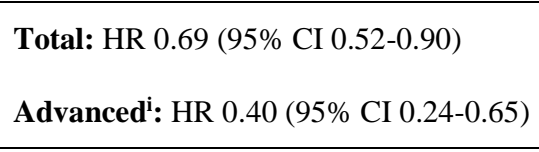 \\
\hline $\begin{array}{l}\text { Fowke } e t \\
\text { al., } 2011\end{array}$ & $\begin{array}{l}\text { Cross } \\
\text { sectional } \\
\text { case control }\end{array}$ & US & $\begin{array}{l}1,304 \\
\text { controls; } 844 \\
\text { cases }(404 \\
\text { advanced) }\end{array}$ & $\begin{array}{l}40 \% \\
\text { simvastatin } \\
, 35 \% \\
\text { atorvastatin } \\
, 10 \% \\
\text { lovastatin }\end{array}$ & - & $\begin{array}{l}\text { Current statin } \\
\text { use vs. nonuse }\end{array}$ & Advanced $^{\mathrm{a}}$ : OR 0.95 (95\% CI 0.73-1.24) \\
\hline $\begin{array}{l}\text { Jacobs et } \\
\text { al., } 2011\end{array}$ & $\begin{array}{l}\text { Prospective } \\
\text { cohort }\end{array}$ & US & $\begin{array}{l}60,059 \text { men; } \\
3,089 \text { cases } \\
(324 \\
\text { advanced })\end{array}$ & NR & NR & $\begin{array}{l}\text { Long-term } \\
\text { statin use ( } \geq 5 \\
\text { years) vs. } \\
\text { nonuse }\end{array}$ & $\begin{array}{l}\text { Total: RR } 1.02 \text { (95\% CI 0.93-1.12) } \\
\text { Advanced }^{d} \text { : RR } 0.86 \text { (95\% CI 0.62-1.18) }\end{array}$ \\
\hline $\begin{array}{l}\text { Tan et al., } \\
2011\end{array}$ & Case-control & US & $\begin{array}{l}1,797 \\
\text { controls; } \\
2,407 \text { cases } \\
(1,681 \\
\text { advanced })\end{array}$ & NR & - & $\begin{array}{l}\text { Current statin } \\
\text { use vs. nonuse }\end{array}$ & $\begin{array}{l}\text { Total: RR } 0.92 \text { (95\% CI 0.85-0.98) } \\
\text { Advanced }^{a} \text { : RR } 0.76 \text { (95\% CI 0.67-0.85) }\end{array}$ \\
\hline $\begin{array}{l}\text { Chan et } \\
\text { al., } 2012\end{array}$ & $\begin{array}{l}\text { Prospective } \\
\text { cohort }\end{array}$ & US & $\begin{array}{l}5,069 \text { men; } \\
356 \text { cases } \\
(195 \\
\text { advanced })\end{array}$ & NR & $\begin{array}{l}\text { Mean } 7 \\
\text { years }\end{array}$ & $\begin{array}{l}\text { Current statin } \\
\text { use at baseline } \\
\text { vs. nonuse }\end{array}$ & $\begin{array}{l}\text { Total: OR } 1.07 \text { (95\% CI 0.82-1.40) } \\
\text { Advanced }^{\mathrm{a}} \text { : OR } 1.04 \text { (95\% CI 0.73-1.50) }\end{array}$ \\
\hline $\begin{array}{l}\text { Freedland } \\
\text { et al., } \\
2013\end{array}$ & $\begin{array}{l}\text { Secondary } \\
\text { analysis of } \\
\text { prospective } \\
\text { trial }\end{array}$ & $\begin{array}{l}\text { Multi- } \\
\text { national }\end{array}$ & $\begin{array}{l}6,729 \text { men, } \\
1,517 \text { cases } \\
(456 \\
\text { advanced })\end{array}$ & NR & $\begin{array}{l}\text { Prostate } \\
\text { biopsy } \\
\text { at } 2 \& 4 \\
\text { years }\end{array}$ & $\begin{array}{l}\text { Statin use at } \\
\text { baseline vs. } \\
\text { nonuse }\end{array}$ & $\begin{array}{l}\text { Total: OR } 1.05 \text { (95\% CI 0.89-1.24) } \\
\text { Advanced }^{\mathrm{a}} \text { : OR } 1.11(0.85-1.45)\end{array}$ \\
\hline $\begin{array}{l}\text { Jespersen } \\
\text { et al., } \\
2014\end{array}$ & $\begin{array}{l}\text { Population- } \\
\text { based case- } \\
\text { control }\end{array}$ & Denmark & $\begin{array}{l}212,400 \\
\text { controls; } \\
42,480 \text { cases } \\
(12,412 \\
\text { advanced })\end{array}$ & $\begin{array}{l}72 \% \\
\text { simvastatin } \\
, 11 \% \\
\text { atorvastatin }\end{array}$ & - & $\begin{array}{l}\text { Current statin } \\
\text { use vs. nonuse }\end{array}$ & $\begin{array}{l}\text { Total: OR } 0.94 \text { (95\% CI 0.91-0.97) } \\
\text { Advanced }^{\mathrm{h}}: \text { OR } 0.90(95 \% \text { CI } 0.85-0.96)\end{array}$ \\
\hline $\begin{array}{l}\text { Lustman } \\
\text { et al., } \\
2014\end{array}$ & $\begin{array}{l}\text { Retrospectiv } \\
\text { e population- } \\
\text { based cohort }\end{array}$ & Israel & $\begin{array}{l}66,741 \text { men; } \\
1,813 \text { cases }\end{array}$ & NR & NR & $\begin{array}{l}\text { Long-term } \\
\text { statin use ( } \geq 5 \\
\text { years) vs. } \\
\text { nonuse } \\
\end{array}$ & Total: HR 0.26 (95\% CI 0.22-0.31) \\
\hline $\begin{array}{l}\text { Morote } \text { et } \\
\text { al., } 2014\end{array}$ & $\begin{array}{l}\text { Retrospectiv } \\
\text { e cohort }\end{array}$ & Spain & $\begin{array}{l}2,408 \text { men; } \\
848 \text { cases } \\
\text { ( } 240 \\
\text { advanced })\end{array}$ & NR & NR & $\begin{array}{l}\text { Long-term } \\
\text { statin use ( } \geq 3 \\
\text { years) vs. } \\
\text { nonuse }\end{array}$ & $\begin{array}{l}\text { Total: OR } 0.88 \text { (95\% CI 0.73-1.06) } \\
\text { Advanced }^{\mathbf{j}} \text { : OR } 1.15 \text { (95\% CI 0.82-1.63) }\end{array}$ \\
\hline $\begin{array}{l}\text { Platz et } \\
\text { al., } 2014\end{array}$ & $\begin{array}{l}\text { Prospective } \\
\text { cohort }\end{array}$ & US & $\begin{array}{l}9,457 \text { men } \\
\text { and } 574 \\
\text { cases }(156 \\
\text { advanced) }\end{array}$ & NR & 7 years & $\begin{array}{l}\text { Statin use vs. } \\
\text { nonuse }\end{array}$ & $\begin{array}{l}\text { Total: HR } 1.03 \text { (95\% CI 0.82-1.30) } \\
\text { Advanced }^{\mathrm{a}} \text { : HR } 1.27 \text { (95\% CI 0.85-1.90) }\end{array}$ \\
\hline $\begin{array}{l}\text { Kantor et } \\
\text { al., } 2015\end{array}$ & $\begin{array}{l}\text { Prospective } \\
\text { cohort }\end{array}$ & US & $\begin{array}{l}32,091 \text { men; } \\
570 \text { cases } \\
(107 \\
\text { advanced })\end{array}$ & NR & $\begin{array}{l}\text { Mean } \\
5.2 \\
\text { years }\end{array}$ & $\begin{array}{l}\text { Current statin } \\
\text { use at baseline } \\
\text { vs. nonuse }\end{array}$ & $\begin{array}{l}\text { Total: HR } 0.86 \text { (95\% CI 0.63-1.18) } \\
\text { Advanced }^{\text {i }: ~ H R ~} 0.62 \text { (95\% CI 0.30-1.28) }\end{array}$ \\
\hline
\end{tabular}




\begin{tabular}{|c|c|c|c|c|c|c|c|}
\hline $\begin{array}{l}\text { Nordstro } \\
\text { m et al., } \\
2015\end{array}$ & $\begin{array}{l}\text { Retrospectiv } \\
\text { e cohort }\end{array}$ & Sweden & $\begin{array}{l}18,574 \text { men; } \\
8,430 \text { cases } \\
(4,242 \\
\text { advanced })\end{array}$ & NR & NR & $\begin{array}{l}\text { Statin use vs. } \\
\text { nonuse }\end{array}$ & $\begin{array}{l}\text { Total: OR } 1.16 \text { (95\% CI 1.04-1.29) } \\
\text { Advanced }^{\mathrm{a}} \text { : OR } 1.25 \text { (95\% CI 1.10-1.42) }\end{array}$ \\
\hline
\end{tabular}

*follow up length reported for cohort studies only

Definition of advanced prostate cancer: ${ }^{\mathrm{a}}$ Gleason $\geq 7 ;{ }^{\mathrm{b}} \geq$ stage $3 \mathrm{~b}, \mathrm{~N} 1, \mathrm{M} 1$ or fatal prostate cancer; ${ }^{\mathrm{c}} \geq$ stage $2 ;{ }^{\mathrm{d}}$ $\geq$ stage 3 or fatal prostate cancer with unknown stage at diagnosis; ${ }^{\mathrm{e}}$ high stage (not defined); ${ }^{\mathrm{f}}$ Gleason $\geq 8$ or regional/distant stage; ${ }^{\mathrm{g}} \geq$ stage $3 ;{ }^{\mathrm{h}} \geq$ stage $3, \mathrm{~N} 1, \mathrm{M} 1 ;{ }^{\mathrm{i}}$ Gleason $\geq 4+3 ;{ }^{\mathrm{j}}$ Gleason $\geq 8$

$\mathrm{HR}=$ hazard ratio; $\mathrm{NR}=$ not reported; $\mathrm{OR}=$ odds ratio; $\mathrm{RR}=$ relative risk ratio 
